Ivanyuk A. V. Influence of public-private partnership mechanisms on health investments in health care. Journal of Education, Health and Sport. 2020;10(10):183-190. eISSN 2391-8306. DOI http://dx.doi.org/10.12775/JEHS.2020.10.10.016 https://apcz.umk.pl/czasopisma/index.php/JEHS/article/view/JEHS.2020.10.10.016

https://zenodo.org/record/4268638

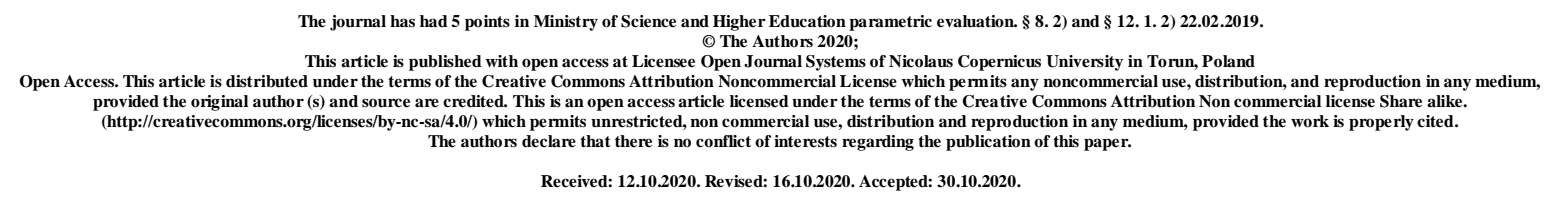

\title{
INFLUENCE OF PUBLIC-PRIVATE PARTNERSHIP MECHANISMS ON HEALTH INVESTMENTS IN HEALTH CARE
}

\section{A. V. Ivanyuk}

\section{Kyiv Regional Clinical Hospital, Ukraine}

\section{Abstract}

The objective. To consider the mechanisms of public-private partnership (PPP) as a way to attract investment into the health care system and find out the existence in Ukraine of a legal basis for the implementation of PPP in health care sector. Materials and methods. The mechanisms and possibilities of PPP projects realization in health care sector have been studied with the use of systematic approach, systematic analysis and information-analytical method. Results. Based on the analysis of international experience, the article presents the key models of PPP used in health care. The legal and institutional bases for the implementation of the PPP investment mechanism in the health care system of Ukraine are determined. The benefits of implementing PPP projects in health care for the state, private partners and the general population are shown. The basic principles of PPP and key directions of introduction of mechanisms of public-private partnership in the field of health care are substantiated. The existing problems for the formation of these mechanisms in the health care of Ukraine are revealed. Conclusions. Public-private partnership is a promising direction of investment attraction in the health care system. There is a necessary legal framework for the implementation of PPP projects in health care in Ukraine. .

Key words: public-private partnership; efficiency; health care. 


\section{Introduction}

To improve the organization of medical care to the population of Ukraine is an urgent task due to the high prevalence of chronic noncommunicable diseases, high mortality, especially among working-age men, and elderly people proportion growth. This leads to increased need of medical care and requires higher costs.

The existing health care system is not able to fully meet the outlined challenges due to underfunding of the sector, low level of material-and-technical facilities, insufficient qualifications of some medical staff.

Today budget funds remain the main source of funding for health care sector in Ukraine. The positive trend to increase these funds has been growing in recent years, but neverthe less they are not be enough to raise the technological level of health care, motivate medical staff to provide quality medical aid at modern standards, provide free or reduced population drug coverage.

All this, combined with the expected rise in the price of medical technologies, necessitates an increase in public funding for health care sector or the use of other ways to attract investment in the industry, in particular through public-private partnership (PPP) mechanisms. The introduction of innovative treatment practices, modern high-tech equipment of clinics, improving of medical care quality, formation of a new institutional structure in the field of health care necessitates the use of private investment. Attracting private capital to the medical sector today is a global trend [1].

The objective. To consider the mechanisms of public-private partnership (PPP) as a way to attract investment into the health care system and to find out the existence in Ukraine of a legal basis for the implementation of PPP in health care.

Materials and methods. Mechanisms and possibilities of realization of PPP projects in health care sector are investigated with the use of the system approach, system analysis and information-analytical method.

\section{Results}

Analysis of world experience shows that investment models of joint participation of the state and private sector in the field of health care take a variety of forms. In some countries, the main emphasis is done on attracting private investment in the creation of new infrastructure, in others - to improvement of the efficiency of existing ones [2, 3, 4].

The practice of PPP projects today includes several key partnership models [5]: Franchising - a private company enters into a contract with a state or municipal customer for the management and operation of an existing health care facility. The private partner invests 
in the equipment of the health care facility, as well as in the equipment and vehicles, ensuring the return of investment and profit from the efficient operation of the facilities.

Model "DBFO - design, build, finance, operate" - a private developer builds a health care facility on the basis of design and specifications set by the state body. The developer finances the facilities's capital expenditures, puts into operation and operates it.

Model "BOO - build, own, operate" - a private developer after the construction of a health care facility transfers it to the state or municipal customer for the period established in the contact. After the expiration of the contract's term the rights for the use of the object remains at the private developer.

Model "BOOT - build, own, operate, transfer" - a private developer operates a capital construction object for a period specified in the contract, after which the ownership of the object is returned to the state or to the municipal customer.

Model "BOLB- buy, own, leaseback" - a private developer builds and puts into operation a health care facility, which is then leased to the state. Lease payments within the prescribed period must cover the value of the object and bring a profit, the rate of which is determined by the contract. In fact, this scheme is an "installment purchase", except that after the lease payments, the state receives part of the facility in proportion to the intermediate amount of payments.

Model Alzira (making contacts for construction and provision of services) - a private developer builds, puts into operation and operates a health care facility, while having a contract for the provision of medical services to a certain category of the population [5].

At present, Ukraine has created the legal and institutional framework for the implementation of investment mechanisms of PPP in health care sector. It includes Law of Ukraine dated 01.07.2010 № 2404-VI "On public-private partnership" [6]; Law of Ukraine dated 24.11.2015 № 817-VIII "On Amendments to Certain Laws of Ukraine on Elimination of Regulatory Barriers to the Development of Public-Private Partnerships and Stimulation of Investments in Ukraine" [7]; Law of Ukraine dated 06.04.2017 № 2002-VIII "On Amendments to Certain Legislative Acts of Ukraine Concerning the Improvement of Legislation on the Activities of Health Care Institutions" [8].

In particular, Article 4 of the Law of Ukraine "On Public-Private Partnership" provides for the use of PPP for the provision of educational and health services.

Public-private cooperation in the field of health care can be carried out through a variety of mechanisms provided by current legislation for cooperation between public and private partners, which are established by concluding various agreements. 
The main mechanism of PPP in the field of health care today includes a long-term, civil law agreement on PPP, which is legally formalized for a certain period and based on pooling resources and risk sharing cooperation of the public partner, on the one hand, and a private partner on the other.

The subjects of the partnership are a public partner (the state represented by the regional administration) and a private partner (a representative of a private business).

The initiator of the contract is a state institution or a state medical enterprise for the needs of which the medical care unit (MCU) is being restructured.

Contractor investor is a natural or legal person who has won the auction and concluded the contract and provides financing (co-financing) of the investment project at its own expense, attracting financial resources of co-investors or borrowed funds.

Public-private cooperation on the basis of the agreement allows to maintain a fairly high degree of state (municipal) control over these organizations (the subject of the agreement) through their representatives in their governing bodies.

The purpose of public-private cooperation in the field of health care on the basis of the PPP agreement is:

- attraction of private investments to health care;

- support and modernization of health infrastructure;

- organization of production of services, financing and carrying out of research works;

- introduction of innovative technologies;

- increasing the level of availability and quality of medical services, efficiency of spending budget funds.

Fulfillment of contractual conditions is mandatory for the partners of the contract, as it is provided by state coercion (law). Any of the contracting parties may be held liable for improper performance of contractual obligations.

Also, in order to ensure the practical implementation of contractual obligations, the PPP law introduces a fairly clear regulation of the processes of initiation, development, evaluation, decision-making on implementation, determination of a private partner for the implementation of the PPP project. A list of public infrastructure that may be the subject of a PPP agreement has been identified.

The advantage of the PPP agreement for the state is that all investment costs are borne by the private partner, thus eliminating the need to divert significant amounts from the budget. And the private partner gets an opportunity to invest profitably own means for a long period 
and it is guaranteed to receive profit. The advantages for the population are to ensure the availability of quality high-tech types of medical services.

The main principles of public-private cooperation in the field of health care are:

- legality;

- socio-economic effect and efficiency;

- validity of management decisions made by public authorities;

- mutual benefit;

- pooling resources to achieve a specific result;

- division of responsibilities and risks between public and private partners;

- providing the public partner with control and monitoring over the implementation of public-private cooperation projects;

- preservation of health care facilities, as well as ensuring the availability and quality of medical care provided under the program of state guarantees of free medical care to the population.

At this stage, the key areas for implementing public-private partnership mechanisms in the field of health care are:

1. Improving the regulatory framework, adopted laws on the basics of PPP in Ukraine.

2. Financial support of PPP projects, assistance in attracting investors to projects in the field of health care.

3. Development of mechanisms for a private investor to ensure the required level of profitability of PPP projects, provided that the social obligations of the state in terms of providing medical care to citizens.

4. Organizational support by public authorities and local governments of PPP projects (from "idea" to "turnkey project)").

5. Training (advanced training) of officials of public authorities, local governments and chief physicians responsible for supporting PPP projects in the field of health care.

We consider all of the above as prerequisites for changing the investment policy in the field of health care and the organization of MCUs on the principles of PPP.

MCU model based on PPP principles will have legal and financial independence, proper material and technical base, economic stability, will integrate advanced forms of organizational - functional and medical - diagnostic processes, which will contribute to the effective functioning of the production infrastructure of the institution as a whole.

The use of international experience in the implementation of PPP projects in the field of health care will allow Ukraine to optimize budget expenditures, systematize the market of 
private medical services and develop it taking into account the real needs of specific regions, invest additional resources in the reconstruction of existing health care facilities; create a network of new clinics based on the latest technologies in medicine, attract highly qualified staff, improve the quality and accessibility of medical services to the population and the level of service.

In the health care sector, PPP will find the greatest application in the implementation of investment projects in the field of infrastructure development of MCUs on the basis of an investment contract - an agreement.

Since the entry into force of the Law of Ukraine dated 24.11.2015 № 817-VIII, the main legal form of PPP projects in the field of health care is an investment contract (agreement). The investment agreement for the implementation of the PPP project best ensures the social interests of society, minimization of risks of the parties, tax regimes, optimization of the organizational structure of the MCUs for the implementation of the legal form of PPP.

The future of Ukrainian health care largely depends on which mechanisms for obtaining services of the required quality will be most effective for the population. Today it is mainly mechanisms of paid medical services and informal payment for medical services. But they do not provide effective protection for patients from the imposition of redundant services and minimize the consequences of medical errors. An alternative is PPP-based MCU, in which an informed mediator economically interested in timely, high-quality and effective treatment appears between a doctor and a patient.

The development of public-private cooperation in the field of health care requires implementation of a consistent state policy to stimulate PPP projects. To implement PPP in the health care sector, it is necessary to determine and approve tariffs for medical services included in the system of state guarantees at PPP, create a system of control over MCUs that work on PPP principles so that they do not inflate tariffs for paid services. And also it is necessary to control the scope and quality of free services provided in accordance with PPP agreement.

Finally, it is desirable to introduce compulsory health insurance and determine the optimal forms of its combination with PPP.

Despite the high economic potential of PPP models use in the health sector, there are a number of problems for the formation and successful implementation of PPP mechanisms in Ukraine. 
In particular, the lack of generalized domestic experience, evaluations of effectiveness, efficiency and possible socio-economic and legal consequences of PPP projects in health care system at the regional and national levels takes place. Lack of a comprehensive approach to the use of PPP mechanisms in health care, with an analysis of legislative, economic and social issues, as well as issues of institutionalization of new models is not rare, too. Lack of a coordinating body that regulates the solution of organizational issues in the implementation of PPP projects in health care is present.

All the outlined problems will have to be solved during the implementation of PPP projects. World experience in the use of PPP mechanisms in health care field shows that modern leaders also started from scratch, and the results they obtained exceeded all expectations.

Conclusions. Public-private partnership is a promising area for attracting investment in the health care system and in Ukraine there is the necessary legal basis for the implementation of PPP projects in health care.

Prospects for further research. To use the results obtained to substantiate conceptual approaches to improving the organization of health care at the regional level.

\section{List of references}

1. Avdeyeva O. V. Razvitiye gosudarstvenno-chastnogo partnerstva v investitsionnykh proyektakh $\mathrm{v}$ sfere zdravookhraneniya. [Yelektronniy resurs] Rezhim dostupu: https: //cyberleninka. ru/article/n/razvitie-gosudarstvenno-chastnogo-partnerstva vinvestitsionnyh-proektah-v-sfere-zdravoohraneniya.

2. Avvakumov A. A. Proyektirovaniy e-modeley gosudarstvenno-chastnogo partnerstva v realizatsii innovatsionnoy deyatel'nosti. /A.A. Avvakumov // Gosudarstvenno chastnoye partnerstvo. - 2015. - Tom 2, № 2. - S. 61-74.

3. Adzhiyenko V. L. Strategicheskiy analiz instituta gosudarstvenno-chastnogo partnerstva v sfere zdravookhraneniya /V. L. Adzhiyenko, N. N. Kosinova // Farmatsiya i farmakologiya. - 2017.- T. 5, № 4. - S.380-400

4. Arzyantseva D. A. Suchasní organízatsíyno-pravoví formi ínnovatsíynogo pídpriêmnitstva / D. A. Arzyantseva, N. P. Zakharkevich // Eurasian Academic Research Journal. - 2018. -№ 1(19). - P.143-155.

5. McKee M., Edwards, N., Atun R. Public-private partnerships for hospitals // Bulletin on WHO 2006;84:890-896 
6. Zakon Ukraïni víd 01.07.2010 № 2404-VI «Pro derzhavno-privatne partnerstvo» [Yelektronniy resurs] Rezhim dostupu: https://zakon.rada.gov.ua/laws/show/2404-17\#Text

7. Zakon Ukraïni víd 24.11.2015 № 817-VIII «Pro vnesennya zmín do deyakikh zakonív Ukraïni shcho do usunennya regulyatornikh bar'êrív dlya rozvitku derzhavnoprivatnogo partnerstva ta stimulyuvannya ínvestitsíy v Ukraïní» [Yelektronniy resurs] Rezhim dostupu: https://zakon.rada.gov.ua/laws/show/817-19.\#Text

8. Zakon Ukraïni víd 06.04.2017 № 2002-VIII «Pro vnesennya zmín do deyakikh zakonodavchikh aktív Ukraïni shcho do udoskonalennya zakonodavstva z pitan' díyal'ností zakladív okhoroni zdorov'ya». [Yelektronniy resurs] Rezhim dostupu: https://zakon.rada.gov.ua/laws/show/2002-19\#Text 